LUZ, Marco Aurélio. Agadá: dinâmica da civilização africano-brasileira. Salvador: Edufba, 2010. 520 p.

\section{AGADÁ: abrindo caminhos para a afirmação da epistemologia africano-brasileira}

\section{Narcimária Correia do Patrocínio Luz}

Nosso propósito aqui é aproximar os (as) educadores (as) de uma das obras mais importantes produzidas no Brasil sobre a civilização africana e seu contínuo nas Américas. Refirome a $A G A D A ́$ : dinâmica da civilização africanobrasileira, de autoria de Marco Aurélio Luz, obra muito citada, pois se tornou alicerce para diversos estudos e pesquisas de muitas gerações nas universidades brasileiras e que, em 2010, comemora 15 anos de publicada.

A obra AGADÁ: dinâmica da civilização africano-brasileira é um dos principais lastros teórico-epistemológicos da equipe de professorespesquisadores do Programa Descolonização e Educação (PRODESE). Pelas contribuições que vem alicerçando em nossas iniciativas, resolvemos apresentar, neste espaço, aspectos que demonstram o quão necessário é atuar na área de Educação, com maturidade de conhecimentos vinculados às comunalidades africano-brasileiras. Eé sobre isso que trata, de modo especial, o livro $A G A D A ́$.

Nossas referências no campo do Direito à Alteridade Civilizatória Africano-Brasileira, que vimos fomentando e sistematizando em nossos trabalhos no PRODESE, (Grupo de Pesquisa vinculado à Universidade do Estado da Bahia e ao Diretório de Grupos do $\mathrm{CNPq}$ ), foram introduzidas na área de Educação nos anos 1980 pelo Professor Doutor Marco Aurélio Luz, na sua atuação no âmbito da Universidade Federal do Rio de Janeiro (UFRJ) e da Universidade Federal da Bahia (UFBA), nas Linhas de Pesquisa e na Pós-Gra- duação sob a sua responsabilidade.

A produção acadêmico-científica do Professor Doutor Marco Aurélio Luz no campo da Diversidade Cultural e Educação, em que a dinâmica da civilização africano-brasileira ganha relevo, se constitui a partir da sua inserção comunitária, o que lhe permitiu vivenciar a primeira experiência de educação pluricultural, no Brasil, a Mini Comunidade Oba Biyi (1976-1986). Durante dez anos, a Mini promoveu, com muito êxito, a educação de crianças e jovens vinculados a uma comunalidade tradicional da Bahia, o Ilê Axé Opô Afonjá, na territorialidade do Cabula, em Salvador, Bahia. O nome da Mini Oba Biyi, que significa, em yorubá, “o rei nasce aqui”, vem da homenagem ao nome sacerdotal nagô de Eugênia Anna dos Santos, a Iyalorixá fundadora do Ilê Opô Afonjá.

Agadá é o nome da espada de Ogum, com a qual ele abre caminhos para a expansão da civilização africana pelos quatro cantos do mundo. Ogum tem o título de Asiwajú o que vai à frente, desbravando, inaugurando caminhos e lidando com o mistério do desconhecido. Está associado ao princípio do ferro, da metalurgia, da transcendência do conhecimento da pedra para os metais.

É ao sabor desse universo mítico-simbólico, que caracteriza o discurso e as linguagens transcendentes, próprias da elaboração de mundo africano, que o autor desenvolve, de modo singular e original, sua abordagem, apelando para o mito como discurso primordial.

Através da simbologia da espada Agadá, Marco Aurélio nos apresenta um fluxo de informações valorosas sobre a instituição das tradições africanas no Brasil, seu universo de valores e linguagens, como também as tensões e conflitos que se estabelecem na relação com as políticas etnocêntricas da Razão de Estado, no decorrer da nossa história.

A singularidade da obra reside, sobretudo, na ruptura que o autor provoca com os limites positivistas, valorizando, a partir daí, as narrativas míticas da tradição africana como fonte da pujan- 
ça do contínuo da civilização africana antes do período colonial e neocolonial. Sublinha, ainda, que o elo mais forte do sistema colonial mercantilista escravista europeu foi o capital financeiro, e nele a atividade mais rentável era o tráfico escravista, que caracterizava a pedra angular do triângulo comercial Europa, África e América.

Por outro lado, o livro nos leva a perceber que o elo mais fraco desse sistema era o próprio tráfico escravista, que proporcionava a incessante vinda dos africanos para as Américas. Esse fato propiciou a expansão constante da insurgência de africanos nas Américas, a exemplo de fatos históricos como Palmares, independência do Haiti, os grandes quilombos da Jamaica, Cuba e, principalmente, a luta de afirmação existencial cotidiana do povo negro, inviabilizando a acumulação mercantil escravista.

As populações negras são apresentadas no livro como sujeitos coletivos da história, que interferem diretamente no fim do tráfico e da escravatura, além de repor, nas Américas, suas comunidades e instituições, baseadas em seus valores, linguagens e formas de sociabilidade das suas diversas tradições.

É importante destacar a coexistência do contínuo civilizatório africano com a civilização aborígine, caracterizando a pluralidade das nações racterizam pelo colonialismo e seus desdobramentos estratégicos, como: catequização, políticas genocidas, políticas de embranquecimento, repressão, recalque; por outro lado, há insurgências negras e aborígines pela afirmação existencial e coletiva dos seus patrimônios civilizatórios. Assim, essa luta envolve, portanto, formas geralmente desprezadas pelos cientistas sociais, ou seja, uma dinâmica na microfísica do poder, rotulada como "cultura”, que abarca as tentativas de impor valores e políticas de abandono para atender ao projeto neocolonial e imperialista.

Agadá inaugura e desbrava caminhos teórico-epistemológicos, indicando que, nos interstícios do Estado moderno, uno e positivista, a comunalidade africano-brasileira repôs suas tradições, instituições e sociabilidades, mantendo com dignidade o legado dos seus antepassados, características essenciais no exercício do direito à sua alteridade civilizatória.

Por fim, insisto aqui em afirmar uma análise que venho desenvolvendo em cursos, palestras, entrevistas, etc.: a contribuição desse clássico, Agadá, para nós, educadores e educadoras, está em nos permitir a compreensão da África e sua expansão nas Américas a partir do repertório das comunalidades que a (re) criaram aqui, tornando-a visceral em nossas vidas.

Agadá Dinâmica da Civilização Africano-Brasileira magnifica a episteme africana, abrindo perspectivas de afirmação do princípio de ancestralidade que dinamiza o estar no mundo de muitas comunalidades na Bahia, portadoras de sabedorias milenares.

(Recebido para publicação em 22 de agosto de 2010) (Aceito em 17 de novembro de 2010)

Narcimária Correia do Patrocínio Luz - Doutora em Educação. Professora Titular Plena do Departamento de Educação Campus I da Universidade do Estado da Bahia (UNEB). Coordenadora do Programa Descolonização e Educação (PRODESE), vinculado ao Diretório de Grupos de Pesquisa do CNPq. Membro da Rede Mundial de Artistas em Aliança pelo Reencantamento do Mundo, onde coordena, na Bahia, o projeto de sua autoria Dayó: compartilhando a alegria socioexistencial em comunalidades africano-brasileiras, indicado como semifinalista, entre os 1.917 inscritos no Prêmio Itaú-Unicef, em 2009; Editora responsável pelo SEMENTES Caderno de Pesquisa, publicação do Departamento de Educação, Campus I da Universidade do Estado da Bahia (2000-2005). Do conjunto das obras, destaque para a mais citada nacionalmente: $A B E B E$ :a criação de novos valores em Educação, Salvador: Edições SECNEB, 2000. narci@ig.com.br. 